\title{
Developing an entrepreneurial mindset for transformational entrepreneurship: The case of Nordic transformative learning circles
}

\section{Victoria Konovalenko Slettli}

\begin{abstract}
Developing entrepreneurial thinking and mindset has recently been on the agenda of the EU policy makers and is a matter of educators' concern. Traditional approaches to entrepreneurial education fail to address the ambiguities of the entrepreneurial process. This paper sets out to explore the learning processes that contribute to developing an entrepreneurial mindset for transformational entrepreneurship. Transformational entrepreneurship refers to a capability and an intended action towards creating change in the life of an entrepreneur and organization which contributes to societal changes and is characterized by the emergence of a new qualitative dimension of possibilities (Staffas, 2017). In order to promote transformational entrepreneurship, a particualar adult learning model known as Transformative Learning Circles was elaborated by Nordic Network for Adult Learning with the support of Nordic Council of Ministers. This article is based on the study of the pilot implementation of the TLC model in the context of Nordic countries. The findings reveal that learning processes promoting entrepreneurial mindsets for transformational entrepreneurship occur in three particular phases: 1) framing the praxis; 2) amplifying the frame of reference; and 3) reinterpreting the praxis. The study extends current knowledge about entrepreneurial learning in two ways. First, it links the key factors influencing entrepreneurial learning to concrete learning processes facilitating the development of an entrepreneurial mindset for transformative entrepreneurship. Second, it illustrates how these key factors may be utilized together in one learning model reinforcing the learning and transformative effect.
\end{abstract}

Keywords: entrepreneurial mindset, transformational entrepreneurship, learning circles, entrepreneurial learning process

\footnotetext{
1 Victoria Konovalenko Slettli, Ph.D., Department of Organization, Leadership and Management, Inland Norway School of Business and Social Sciences, Inland Norway University of Applied Sciences. Telthusveien 12, 2450 Rena, Norway, e-mail: victoria.slettli@inn.no (ORCID ID: 0000-0003-4658-6206).
} 


\section{INTRODUCTION}

This paper addresses the problem of developing entrepreneurial mindsets for enhancing transformational entrepreneurship. Given the challenges of globalization, aging populations, increasing migration, and increasing disparity between the rich and the poor, countries and governments are searching for solutions that can produce a positive impact on socioeconomic development. One of the proposed solutions relates to promoting transformational entrepreneurship in regions across the world (Ratten \& Jones, 2018; Maas, Jones, \& Lockyer, 2016).

The concept of transformational entrepreneurship is still in its infancy. According to Miller and Collier (2010, p. 85), transformational entrepreneurship "transcends economic terms and emphasizes the centrality and value of people, their vocations, and the many levels of relationality involved in entrepreneurship, in addition to the technical aspects of the business." It is based on the principles of supporting the interconnectedness of people and environments to facilitate adaptation and transformation through change, as well as decision-making in the conditions of uncertainty. By encompassing sustainable practices it may provide an impact on society through creative solutions that enable change and maximize economic and long-term societal impact (Ratten \& Jones, 2018). In this paper, transformational entrepreneurship is understood as a purposeful action and a capability of bringing about changes in the life of an individual (entrepreneur) and in the organization where an individual is involved by contributing towards "global societal changes that involve the emergence of a new qualitative dimension of possibilities and conditions" (Staffas, 2017, p. 19). Meanwhile, entrepreneurship means initiating something new; transformational entrepreneurship refers to engaging in actions that "involve movements and creations in an entirely new dimension" (ibid.).

Entrepreneurship can be understood in terms of a particular type of mindset (McGrath \& MacMillan, 2000) that can be developed through higher education programs, lifelong learning settings, and vocational training (Kakouris, 2015). Lamberton, 2005, p. 162 defines mindset as a "habitual or characteristic mental attitude that determines how you will interpret and respond to situations." Täks, Tynjälä, and Kukemelk (2016) suggest that an entrepreneurial mindset is related to such skills as the ability to identify opportunities, creative problemsolving, strategic thinking, networking, life-long learning, resilience to failures and decision-making in the situation of uncertainty.

Worldwide educators are preoccupied with educational programs that would assist in developing the skills of seeking and seizing opportunities inherent to entrepreneurial mindsets (Oyugi, 2015; Leon, 2017). However, 
the general consensus is that traditional pedagogical approaches are "insufficient to adequately develop entrepreneurs," and there is a growing need to "cultivate innovative ways of thinking ... to fully enhance and develop entrepreneurial approaches to education and learning" (Higgins, Smith, \& Mirza, 2013, p. 135). Acknowledging the need for novel approaches that would promote entrepreneurial thinking and mindset, along with the importance of transformational entrepreneurship for local and regional development (Maas, Jones, \& Lockyer, 2016) this paper addresses the following question: What learning processes promote the development of entrepreneurial mindsets for transformational entrepreneurship?

In order to answer this question, the paper presents a case study of an adult learning model called Transformative Learning Circles (TLC). The TLC model was elaborated by the Nordic Network for Adult Learning (NVL) with the support of the Nordic Council of Ministers for the purpose of promoting transformational entrepreneurship. The overall learning objective of the TLC model was to promote the integration of an entrepreneurial mindset as part of the individual's work activity and as an embedded cultural element in different social and organizational contexts. The pilot project of the TLC model was carried out in 2015-2017 in the Nordic setting including five countries: Denmark, Sweden, Norway, Finland, and Iceland. To answer the question of interest, this paper addresses the learning processes within the TLC model and discusses how they promote entrepreneurial mindsets for transformational entrepreneurship.

The findings suggest that learning which promotes transformational entrepreneurial mindsets occurs in a dynamic iterative loop where individual level learning is combined with knowledge-sharing and interaction at the group level. Three particular phases can be distinguished within the learning processes: 1) framing the praxis; 2) amplifying the frame of reference; and 3) reinterpreting the praxis. Furthermore, learning occurs as a result of instances that permit knowledge conversion between its tacit and explicit modes. The effect of the TLC learning processes on enhancing entrepreneurial mindsets for transformational entrepreneurship is illustrated in terms of learning outcomes.

The paper has the following structure. The next section provides an overview of the literature on entrepreneurial learning. The paper then describes the research method and introduces the case study of the TLC learning model. The following section presents the findings of the study describing three phases of the learning processes. The section is closed by proposing a conceptual model for the development of an entrepreneurial mindset for transformational entrepreneurship Finally, the paper offers a conclusion highlighting theoretical and practical implications of this research. 


\section{LITERATURE REVIEW}

\section{Preconditions for fostering an entrepreneurial mindset}

The overview of the literature on entrepreneurial learning and education suggests several important factors for the development of entrepreneurial thinking and mindset that are considered in this section in more detail.

First, the nature of entrepreneurial learning is, to a large degree, experiential (Krueger, 2007; Kolb, 2014; Kakouris, 2015). This corresponds with the literature on experiential education. Particularly, learning occurs through experience from an interaction with a process and then transferring this experience into a new context/situation (Dewey, 1986). Knowledge is a set of experiences, but only by making use of and engaging in practice do we derive meaning and value from these experiences. However, experiential learning is not complete until it extends to a deeper cognitive reflexive learning (e.g., Higgins \& Elliott, 2011; Pittaway \& Thorpe, 2012; Fayolle, Pittaway, Politis, \& Toutain, 2014). Therefore, critical reflective practice is important for fostering the development of entrepreneurial mindsets (Higgins, Smith, \& Mirza, 2013; Kakouris, 2015; Lindh \& Thorgren, 2016; Tikkamäki, Heikkilä, \& Ainasoja, 2016).

One of the ways to trigger the reflective process is by employing the principle of learning from critical events (or critical incidents) - a notion loaned from the cognitive psychology literature. Critical events refer to unexpected events that disturb the normal course of activity. Such events become triggers for reflection as they prompt humans to combine previous experiences and new ideas while reconsidering existing thoughts and actions (e.g., Woods, 2012). Scholars have emphasized the role of critical events for entrepreneurial learning and, in particular, learning how to deal with risk and uncertainty (e.g., Cope \& Watts, 2000). In the research literature, critical events were presented as inalienable parts of entrepreneurial learning (Kolb, 2015; Lindh \& Thorgren, 2016). Lindh and Thorgren (2016) argue that in order to develop an entrepreneurial mindset, one should possess an ability to recognize which events are critical to reflect upon and take action. Furthermore, for critical events to be useful for developing entrepreneurial thinking, learners must "recognize and define their thoughts, emotions and behaviors, and relate them to different conditions and judge them in relation to entrepreneurial determinants" (ibid., p. 538). Reflective learning does not start with the experience of a critical event, but with the ability to recognize such an event (ibid.). In this connection, authors suggest that critical event recognition should be addressed in teaching efforts including training entrepreneurs to detect their own thoughts, emotions, and behavior in different situations. The difference in cognitive preparation might provide 
an explanation of why some individuals learn from failures and unexpected events, whereas others don't.

Even though the critical incidents approach is recognized as useful in entrepreneurial learning, some scholars argue that it does not go far enough in aiding people to learn in a more reflexive manner (Higgins, Smith, \& Mirza, 2013). In order to develop reflexive awareness, entrepreneurial learning should make use of reflexive critiques. Reflexivity implies questioning one's own practice and assumptions (ibid.). Furthermore, experiential learning yields its fruits when it is triggered by reflection upon one's own learning experiences (Cope, 2003). This is in line with the notion of self-critical reflection described by Mezirow, 1991 who connected learning with developmental educational psychology. Self-critical reflection denotes the ability to dispute one's own assumptions and stereotypes, "a uniquely adult form of metacognitive reasoning" (Mezirow, 2003). Metacognition refers to thinking about one's own thoughts and selfreflection about one's own reasoning, which is concerned with the validity of one's own thinking (Kakouris, 2015). The literature sees metacognition as a dynamic learned response that can be enhanced through training (Haynie, Shepherd, Mosakowski, \& Earley, 2010; Liang, Lee, \& Liang, 2015).

Reflecting on events or breakdowns in the practice of an entrepreneur may lead to "transformative learning" (Cope, 2003; Taylor \& Thorpe, 2004). The concept of transformative learning was first introduced by Mezirow (1978) within the context of adult education. Mezirow defined transformative learning as "the process by which we transform problematic frames of reference (mindsets, habits of mind, meaning perspectives)-sets of assumption and expectation-to make them more inclusive, discriminating, open, reflective, and emotionally able to change. Such frames are better because they are more likely to generate beliefs and opinions that will prove more true or justified to guide action" (Mezirow, 2009, p. 92). Transformative learning theory implies a metacognitive assessment of instrumental and communicative reasoning that comprises two aspects: critical (self-) reflection on assumptions and participation in dialog to ensure the best reflective judgment. To summarize the second point, an entrepreneurial mindset is metacognitive in nature, and therefore inclusion of metacognitive training in entrepreneurship pedagogy fosters entrepreneurial thinking (Haynie, Shepherd, Mosakowski, \& Earley, 2010).

Finally, developing entrepreneurial thinking is a process of co-creation in human interaction involving both educator and learner who co-construct learning experiences (Higgins, Smith, \& Mirza, 2013). This understanding is in line with the assumptions of the social constructionism paradigm. According to the reflexive pedagogy approach, entrepreneurial learning is an enacted product of experience which comes through interactions with others who 
have different ideas (ibid.). Educators and learners actively participate and engage in creating new ideas by reflecting critically on their current practices. The contradiction of opinions might cause a person to question their own usual practices and start seeking alternative ways. Entrepreneurial learning here is a relational practice in which shared meanings are created through reflexive questioning, critiquing, and challenging the current state of things.

To summarize, experiential learning, critical events recognition, reflexivity and metacognition, transformative learning, and co-creation of learning experiences are all important factors and principles for developing an entrepreneurial mindset. However, even though these factors are known, it is their unique combination that might produce a difference for the entrepreneurial learning enabling transformation. The following sections address in more detail, how the TLC model combined the above-mentioned factors in a way to facilitate learning processes for fostering an entrepreneurial mindset and achieving change at the individual and organizational level.

\section{RESEARCH METHODS}

The research data was collected by a team of eight Nordic researchers as a part of the evaluation of the TLC pilot project (Staffas, 2017). The exploratory study was partially guided by Reason and Rowan's (1981) human inquiry paradigm emphasizing the importance of involving all relevant actors in the research process. The principles central to this approach suggest that all the involved actors can contribute to deciding what to look at, the methods of inquiry, and making sense of the findings. While carrying out the study, the data collectors sought to maintain a critical distance by minimizing their influence on the implementation of the pilot TLC project. The data collection took place between August 2016 and March 2017. A mixed-method approach was adopted in order to obtain a deep understanding of the TLC model, its implementation, and learning processes. In particular, data were collected through individual interviews with the TLC participants and facilitators (11 in number), focus group discussions (5), analysis of the logs which TLC participants filled in, observation of the TLC circle meetings, informal conversations with the TLC participants, and a final survey. The semi-structured open-ended interviews and focus group discussions varied between 45 and 70 minutes and were taperecorded and transcribed for the purposes of analysis. Most interviews were conducted in English, but Swedish, Norwegian, and Danish were also used. Observation of the physical and digital TLC meetings gave a better insight into the dynamics of the learning circles. The individual logs provided a wealth of information to support the data granted from the individual interviews. 
Informal conversations with the TLC participants improved understanding of the learning needs, processes, and outcomes. Finally, 12 participants provided their answers to the questions of the anonymous final survey.

To secure credibility of the study - that is, accuracy of understanding, interpretation, and representation of the research results (Ritchie, Lewis, Nicholls, \& Ormston, 2013; Lincoln \& Guba, 1985)-several measures were taken. In order to obtain credibility of understanding in the phase of data collection, multiple sources of evidence were used; in other words, the method of triangulation was employed (Ghauri \& Grønhaug, 2005). Credibility of interpretation was enhanced through theory triangulation (Ritchie, Lewis, Nicholls, \& Ormston, 2013) by looking at empirical data from different theoretical perspectives. In order to verify the findings and provide a sensible representation of the information obtained, the preliminary findings were presented to the circle participants in a physical meeting where the feedback from the participants was obtained. In this way, data, analytic categories, and interpretations were tested with the respondents from whom the data was originally obtained-a validation technique known as member check (Lincoln \& Guba, 1985). Finally, credibility of representation was secured by using citations from the interviews and focus group discussions with the respondents, whose identity is kept anonymous.

\section{ANALYSIS, STUDY AND RESULTS}

\section{The case of the Transformative Learning Circles}

\section{The TLC learning model}

Transformative Learning Circles is an adult learning model that was developed by Nordic Network for Adult Learning (NVL)-a network for entrepreneurial learning and innovation, with the financial support of the Nordic Council of Ministers. Two core elements lie at the heart of the model: learning circles and a log system identifying critical incidents. The notion of the learning circles refers to a non-formal and purposeful approach to adult education where a group of people comes together to investigate an issue of common interest. This usually includes initial planning and a series of meetings with specific goals that members of the circle wish to achieve during the meetings. It is suggested that learning circles allow participants to focus learning upon their own practice and encourage them to act "as critical investigators promoting dialogue and collaborative inquiry" (Ravensbergen \& Vanderplaat, 2010 , p. 340). Further, the problem-solving approach pertinent to the learning 
circles "awakes" critical consciousness or critical reflection and enhances the sharing and use of participants' skills and experience (ibid.).

For the pilot project, three learning circles were established. In total, 25 people participated in the pilot TLC project, 12 male and 13 female participants, aged 25 to 60 years. All participants hold working positions in the private or public organizations representing different sectors. Circle participants originated from five Nordic countries: Norway, Sweden, Denmark, Finland, and Iceland. These were practitioners with diverse professional backgrounds in consulting, research, public service, and the educational sector. Participants represented a mix of actual entrepreneurs owning their own firm (for example, occupied with coaching, training, consultancy), and practitioners employed by different organizations (for example, in the university sector or public service).

The circles were organized around three major themes: (1) entrepreneurial learning and innovation in education (7 participants); (2) entrepreneurial learning and rehabilitation in workplaces (10 participants); and (3) entrepreneurial learning and integration (8 participants). The first circle consisted of educational and pedagogic experts. The second circle encompassed consultants, academics and public servants working with innovation and networks. The third circle included social workers and daycare personnel who worked with newcomers and immigrants and their inclusion in Nordic countries. The participants for each circle were chosen by the circle leaders (facilitators) based on individual acquaintance and connection to the NVL. National and professional diversity was seen as an important precondition of the TLC model, a factor that could increase the potential for learning. The common feature of the TLC members was interest in entrepreneurial learning, promoting innovation, and active participation and involvement in the TLC program.

According to the TLC model, the participants were engaged in two types of activities over a 9-month period: participating in the circle meetings (physical and digital) and keeping the logs. The kick-off for the circles took place in May 2016 in Västerås, Sweden. The second round of circle meetings was held the same year in Norway. The participants of one circle met in August in Elverum, while the two other circles met in October in Hamar. The third round of circle meetings took place in January 2017 in Uppsala, Sweden. These particular places were chosen on the basis of convenience and availability of the facilities to host the circle meetings. The length of the physical meetings varied between one and two days. In between physical circle meetings the participants arranged digital meetings via Skype to discuss the interim progress, reflect on the physical meetings, and suggest improvements in order to achieve the best possible learning environment. Each circle decided itself the frequency and 
agenda of these Skype meetings. On average, the circles met on Skype one to two times in between physical meetings.

\section{The log system}

Each participant of the TLC had his/her own development/work project with which he/she was preoccupied professionally. The log system was used to document activities, experiences, and reflections related to individual development projects. Circle participants were expected to keep the logs in between physical meetings. The logs were set up in a matrix system according to the following logic. Each participant was to keep a general individual log book, from which they would extrapolate a critical incident log, and further formulate an individual learning log (Figure 1).

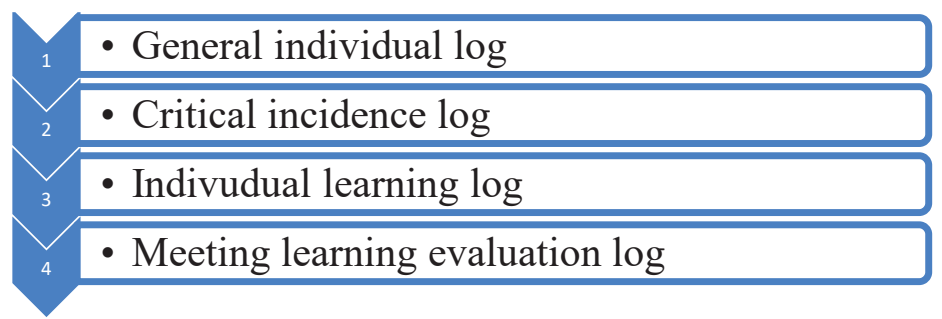

Figure 1. The log system

The general individual log draws on the Guiding Principles-key questions and indicators of transformation (see Attachment 1). The Guiding Principles were elaborated as a part of the model assuming that transformative action can be derived from a guiding principle and that the transformative quality of the action taken can be verified by an indicator of transformation (Namdar, 2016). In this log, participants could reflect on their own actions, and attempts that would foster change in themselves or in their organizations.

In the critical incidence log, participants could register critical events associated with individual or organizational transformation. Critical incidents could be actions, thoughts, or events that had happened and made a transformative impact on the person who reported them.

The TLC participants used individual learning logs to document what they wanted to share during the next circle meeting. One critical incident was to be chosen from the individual log book, followed by an analysis of what the person and/or her working place had learned.

Finally, during the circle meetings, the meeting learning evaluation log was to be filled out by the circle facilitator with the assistance of the circle 
participants. For this log, each participant could choose one particularly interesting aspect of the learning process taking place during the circle meeting which would benefit from further development.

The log system was thus designed to seize learning experiences, reflections, and outcomes at the individual and group level (see Attachment 2 for the illustration of the log system).

\section{Facilitation in the TLC}

The purpose of facilitation was in line with the overall purpose of the TLC model-that is, helping a group of people to discover new modes of thinking and acting that would cause transformation at the individual, group, or organizational level. The circle leaders were assigned the role of facilitators and therefore needed to have knowledge of adult learning and facilitating methods. The facilitators played a double role in the TLC model; in being both facilitators and participants, they were charged with finding a balance between these two roles. For the purposes of transformative learning, it was important to create and maintain an atmosphere of trust and support in the learning environment. Facilitators, who were to encourage others (and themselves) to challenge habitual ways of thinking and acting, were to send the signals that would promote openness, mutual respect, and tolerance (Ndlela, Hole, Slettli, Haave, Mei, Lundesgaard, Hermanrud, Staffas, \& Namdar, 2019).

The work of facilitation was organized in a three-step cycle structure: before, during, and after the circle meetings. In the time preceding the circle meeting, facilitators were to prepare for the circle work by reading the members' logs, in particular, the critical incidents logs, in order to highlight themes for discussion. In addition, facilitators invited group members to contribute to the agenda of the next circle meetings.

During the circle meetings, facilitation was carried out through the use of various tools and methods for conversations and knowledge sharing. In some circles, facilitators could bring in their own critical incidents to trigger the discussions. The work of the circles followed the logic of deliberative discussion (Burkhalter, Gastil, \& Kelshaw, 2002) where the central elements were dialogue, questioning, and active engagement (Stein, 2009). At the end of the meeting, facilitators were responsible for facilitating an evaluation of the learning process that took place during the meeting. 


\section{DISCUSSION}

\section{The TLC learning processes and their characteristics}

The process of learning in the TLC took place as a dynamic iterative loop in the interplay between individual and collective domains. While analyzing the implementation of the TLC model, three concrete phases of transformative learning can be distinguished:

1) Framing the praxis.

2) Re-framing: amplifying the frame of reference.

3) Reinterpreting the praxis.

The notion of praxis implies the manner in which people are engaged in the world and with others (Ramsey \& Miller, 2003). The phases of the learning process facilitating the development of entrepreneurial thinking and mindset are summarized in Table 1, which can be read as follows. Three phases of learning process are described based on several dimensions. The first dimension refers to the individual vs collective domain of learning. The second dimension reflects the mode of knowledge conversion - between tacit and explicit (Nonaka \& von Krogh, 2009). The third dimension describes learning practices of the TLC model at each phase of learning. The fourth dimension refers to the key theoretical concepts that explain the core of each learning phase. Finally, some examples of the TLC participants' survey feedback support and illustrate the learning processes at each phase. A more detailed description of each phase is provided below.

\section{Phase 1. Framing the praxis}

As part of the preparation for the circle meetings, the participants were engaged in filling in the general log and extrapolating critical incidents followed by the individual learning log. The logging was supposed to be related to the circle participants' individual development projects. This task involved a lot of comprehension work where the participants made efforts to project the work practice against the theory of guiding principles-in other words, to frame their own praxis. This implied converting the tacit knowledge of everyday work practice into explicit statements specified through guiding principles and transformation indicators. Several TLC participants described logging as a good tool for reflection:

"Definitely the time to reflect. To sit down and think why things became the way they did and how my acts influenced the process. Filling out the logs was important for establishing this deep reflection" (TLC participant, final survey). 


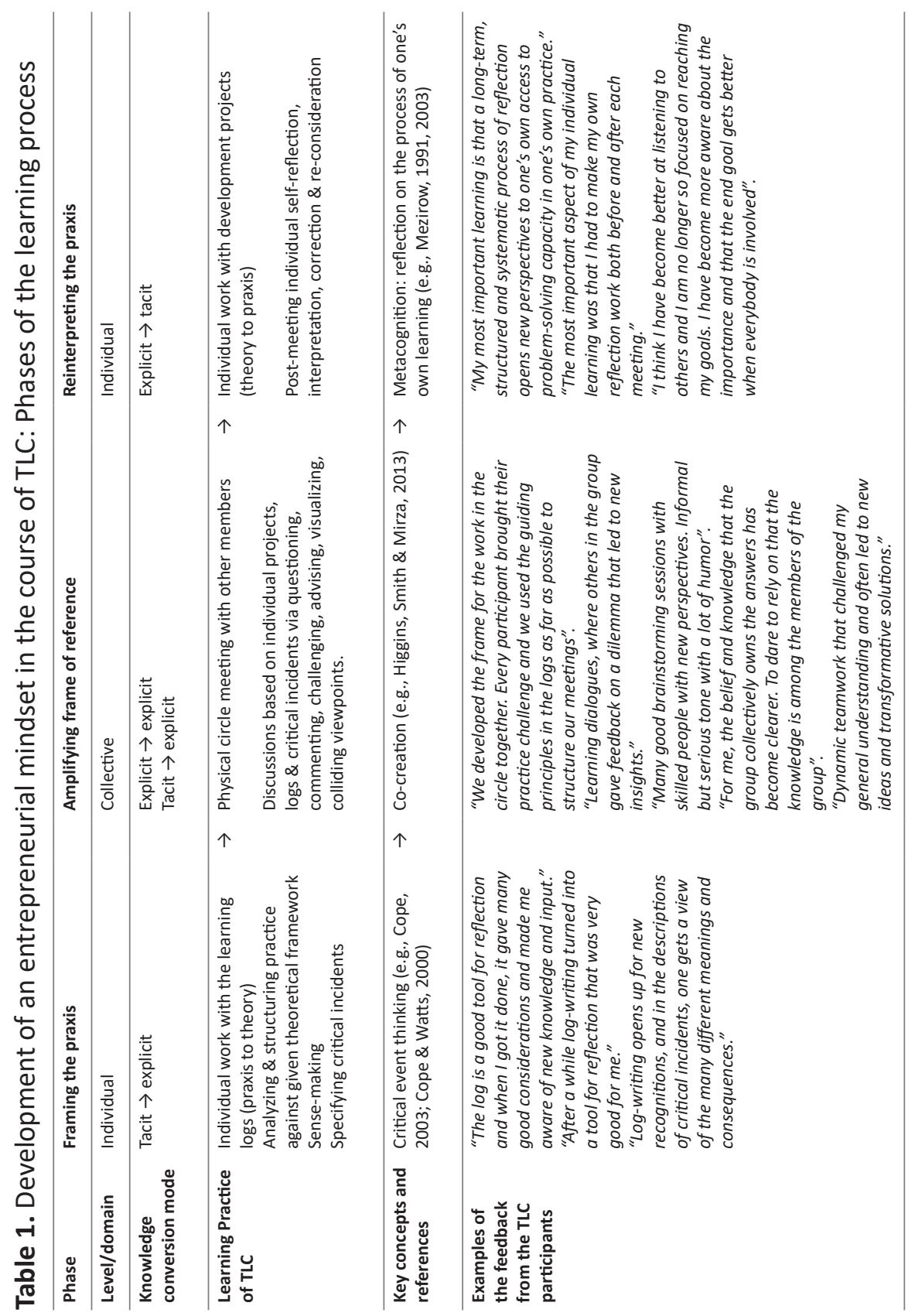


At times, reflexive work behind the log activity was more important than filling in the logs: it helped to understand sequences of critical events and their consequences. Framing the praxis by filling out the logs provided participants with a deeper meaning of their everyday work situations and understanding of the multiple meanings:

"The log-writing has been a good experience for me... Through the logwriting, I realized the relation between different activities that I am involved with... Log-writing opens up for new recognitions, and in the descriptions of critical incidents, one gets a view of the many different meanings and consequences which this experience can bring for the future work" (TLC participant, interview).

Since the logs were to be used in the circle discussions, the participants sought to make them meaningful both for themselves and the others:

"Also, the balance between too general and too specific... Because it can be very long with a lot of bunch of details that are not important for others to read, but it can also be so short that it's too general so, as a matter of fact I could just cut and paste what you have written to my own log because it's so general that it just fits. So I think that's, we need to find balance in how detail we are and how general we are. But I think for me, at least, it has been very reflective - self-reflective to fill up these logs" (TLC participant, focus group).

Logging was a challenging task in terms of time used and effort to understand the system and logic of logging, the logic of guiding principles, and recording events/critical incidents in a meaningful manner. Because of these challenges, some of the participants reduced individual logging to critical incidents only. Some of the participants experienced logging as a twofold activity, first by recording the "data" concerning their own praxis. This "data" was mostly seen as the source of information and learning for other circle participants. Second, the participants engaged in "learning" from their own records. This entailed individual, personal learning from their praxis. The participants learned that these two functions of the logs were somewhat at odds with each other, posing a challenge for framing their praxis in a way that was meaningful for everybody.

\section{Phase 2. Amplifying frame of reference}

The way circle meetings were organized, the learning environment, the facilitation mode, and co-construction of solutions created possibilities for the participants to amplify their own frame of reference and approach their individual development projects in more mindful and reflexive ways. 
Circle meetings were important as the places for developing new ideas and approaches. The collective domain provided the impulse necessary to stimulate individual learning. The participants were sure that "the energy was in the group." The interaction of participants during the circle meetings made them "feel brave, get energy, challenge themselves, and get strength for the development work."

The circle participants belonged to the same type of context or work setting (for example, higher education) and yet had different challenges. In the beginning of the circle work, one of the participants would start with presenting his/her development project and logs or critical incident. Further, all circle members would receive an invitation to participate in the discussion. The discussion included questioning and commenting, challenging opinions and advising, visualizing, and presenting colliding viewpoints:

"When I read something in a book, for example, it makes sense to me that oh, I should do this and this and this makes sense or something like that. But when we talk about it in this circle, the other participant's challenge what has been written ... it gives me another reflective level than just, just ... reading, you know a book" (TLC participant, focus group).

"And you all bring lots of new value to my thinking because you say things that I wouldn't necessarily think by myself ... I think there's diversity in it, I think I learn when I speak and I learn when I listen. And I think there's a high level of reflection-but you have to learn that" (TLC participant, focus group).

Participants were enthusiastic in discussing and sharing their opinions and asked critical, challenging, and reflective questions. The learning environment was characterized by participants themselves as an environment facilitating "trust, curiosity, understanding, open discussions, and challenging questions" and was safe enough to raise disagreements.

When listening to the presenter's case, the circle participants could advise with reference to their own experience. The logs were actively used in the process of learning and sharing experiences of the circle participants:

"...we went through my log actually today. How did I fill it out, what was missing, what was, what did I mean when I wrote it down and so on and that gave me again another reflection..." (TLC participant, focus group).

Participants often attempted to visualize their problems, challenges, and solutions in models, drawings, and pictures. In general, learning in the TLC circle meetings was a joint process of co-creation where every circle member contributed with his/her comments, ideas, remarks, experiences, questions, etc. 
The above-described arrangement of circle meetings permitted the amplification of participants' frame of reference-that is, to expand their understanding of the phenomenon in question by encompassing new perspectives and viewpoints. This reframing shows, for example, in understanding the need for "getting outside one's own perspective, and trying on different roles" when solving the challenge of the development project or seeing the need to "be more reflective at the personal level" (from the Meeting Evaluation Log).

From the point of knowledge sharing, the reframing was activated when the participants were sharing both the tacit knowledge of personal experience and explicit knowledge codified in the logs and transforming it into the explicit knowledge shared by all circle participants.

At the individual level, for some participants, the process of reframing resulted in an understanding of "the need to see one's own development project in a wider perspective and taking a step back to change it." For other participants, it was important to "focus on what happened as a result of the way" the person worked. For the third, the challenge was to "see bigger processes behind" their expert area (citations from the Meeting Evaluation Log).

\section{Phase 3. Reinterpreting praxis}

The third phase of the TLC learning processes can be described as circle participants reinterpreting their own praxis. In between the circle meetings, the individuals were engaged in interpretation of what they discussed at the circle-meeting, re-consideration of their old ways and approaches, and further search and correction to use the new ones.

Upon coming back home from the TLC circle work, the participants returned to their customary work tasks and the practice of development projects:

"And this is also a great opportunity to take something that we face on a daily basis out of that context and bring it here like a totally new environment and evaluate it ... maybe I have thought about this in a totally different way or a wrong way, and then bring it back to the daily context and see if something is different" (TLC participant, focus group).

To make sure the individual learning took place, it was important (and challenging) to connect the energy and reflection in the circle meetings with the individual and the development projects at home which took place between the circle meetings. In other words, the task was to convert the explicit knowledge gained at the circle meetings into the tacit knowledge of the new work practice. The participants were aware that this step required 
their motivation, will, and commitment, as well as empowerment-the possibility to produce change in their organizations:

"If ... you wouldn't have permission from your organization to change anything at organizational level, but still, you can make the change in personal level. And, there's some kind of value in that too, so when maybe you realize that you're not working in the right organization and you want to change your life" (TLC participant, focus group).

Reinterpreting the praxis included not only the amplification of one's own knowledge by encompassing new perspectives, but also metacognitive thinking implying reflection on one's own learning. In this way, the TLC promoted the development of metacognitive skills - the skills critical for an entrepreneurial mindset (Haynie, Shepherd, Mosakowski \& Earley, 2010, Cho \& Jung, 2014):

"The most important aspect of my individual learning was that I had to make my own reflection work both before and after each meeting" (TLC participant, survey).

"My most important learning is that a long-term, structured and systematic process of reflection opens new perspectives to one's own access to problem-solving capacity in one's own practice" (TLC participant, survey).

The nature of learning in the TLC can be described as additive, gradual, and incremental. According to the participants, it was not the revolutionary new knowledge they returned home with. Rather, it was "reasoning" that occurred as a result of meeting and interacting with peers. The participants experienced their learning as a process of "taking a little step further in their knowledge." Referring to the TLC participants, in their work-life, they tried to make this little step forward in everyday praxis.

\section{Learning outcomes and change effect in the TLC}

The TLC participants expressed that participating in the TLC helped them to create a space for reflection-a rare opportunity in their busy lives. In this space, they could reflect about possibilities for their project development (reflection on practice) while interacting with their peers (reflection in practice):

"TLC isn't only about learning from experiences and learning from mistakes. You don't learn without reflection, you have to go deeper in your search for answers" (TLC participant). 
Moreover, this space permitted reflection about their own learning process. For instance, the participants reported that because of participation in the TLC, they started reflecting on the choices they made and personal habits, including their own mindset and behavior. The TLC provided a liberating context for reflection on individual roles and interests.

"It is exactly that one reflects not only on the technical level of learning but also about one's own role and interest within the context which also has strong liberating qualities ... One opens up for several possible roles and resources" (TLC participant).

Part of the individual learning process involved something the participants referred to as "unlearning." In order to learn and act in the new ways, the TLC participants recognized the importance of "unlearning" their customary roles. Getting rid of professional masks, encompassing ease and "playfulness" was a significant part of the learning process having impact on embracing new ideas and creativity.

"When one works a lot with people who are decision makers in different authorities, then it's not always fruitful to sit around such a table like this: then it's very much "I wear this jacket," and my role is so. In this case, one may actually need to take out that role and provoke playfulness" (TLC participant).

Learning at the personal level in the TLC took place in terms of seeing things in a different light and intensifying reflexive practice that brought intrapersonal change and change in patterns of behavior. To illustrate this, some examples of the individual learning outcomes are provided below:

- a TLC participant said that due to the TLC work, he had changed towards being more tolerant;

- a TLC participant mentioned that he had learned a lot about himself. Furthermore, he felt that he had become braver and had improved his working methods;

- a TLC participant expressed that she became more curious about her own practice, as well as that of her colleagues. The result was "seeing things differently and seeing new things";

- a TLC facilitator recognized that because of participation in the TLC and working with logs and critical incidents, he became more aware of the "critical incident thinking." This included, for example, how the individual learning curve may change based on the choice of the critical incident. The facilitator said that he reflected on a number of questions-for example: Is the critical incident really a critical one, and at what point of time? How does the choice of the critical incident affect future learning and practice? Is one able to manage the process of one's own learning? In this way, meta-reflection on 
one's own learning took place. Further, the facilitator was engaged in reflections about his personal behavior. This resulted in changing the pattern of his communication with colleagues. Thus, meta-reflection on one's own practice led to changes at the personal level.

The intended purpose of the TLC model was to promote the development of an entrepreneurial mindset for transformational entrepreneurship with the outcomes both at the personal and organizational levels. The study of the pilot TLC project suggested multiple pieces of evidence of such development at a personal level. Further, the study also provides some examples of transformational entrepreneurial behavior at the organizational level.

The first example concerns the adoption of the log system in the entrepreneurship course taught by one of the TLC participants at his home academy. The TLC participant not only adopted the log system for his course but also modified it. He simplified the complex system of logs located in several word documents into one electronic log which he made available for the students as a mobile application. The TLC participants commented that the original log system was quite challenging both in terms of understanding and use. The above-mentioned participant took into consideration his own user experience of the log system as well as comments of the peers and transformed it into a more user-friendly and easily-accessible electronic version. He did so while preserving the core of the log system-the guiding principles and the critical event recognition. The result of this modification-an electronic version of the log system which was used by the entrepreneurship students - was presented to the delight of all TLC participants at the final TLC evaluation meeting. Implying that "entrepreneurial behavior that goes beyond current expectations" is considered to be transformational (Ratten \& Jones, 2018 , p. 4), this example presents an indication of social transformational entrepreneurship with the effect on the organizational level.

Another participant reported how the individual perception of his own professional abilities was changed as a result of the TLC, and how this change in mindset influenced his entrepreneurial activity at his work place:

"One of the most important learning and understanding that developed in me... was that I'm (now) capable to work with international professional education group, and that my know-how can be applied with multicultural environments with other professional fellow colleagues and people who work with education. I see this as a critical part of my developing professional identity. I feel that without our group and TLC as a format, this development would have taken much more time to happen. Or it could be possible that I would have never taken the step forward with starting to cooperate with this depth with multicultural groups. After experiencing TLC, I have had the 
courage to mentor and coach multicultural groups in my university of applied sciences. I will take responsibility to create new six-month entrepreneurship side subject for multicultural student group, and I actively search new opportunities to collaborate with new partners in different countries. This is something I feel is the most valuable that I got out of the TLC. This is something for me personally, but also for the organization I work in" (TLC participant, individual interview). With reference to the examples above, the study of the TLC pilot project provides evidence of the TLC participants developing an entrepreneurial mindset resulting in a learning and change effect both at the personal and social/organizational level. In the context of this study, the change efforts undertaken by the TLC participants at the organizational and social levels constituted the essence of transformational entrepreneurship.

The findings of the study and the discussion above can be summarized in a conceptual model for the development of an entrepreneurial mindset for transformational entrepreneurship (see Figure 2). According to this model, the learning processes facilitating the development of an entrepreneurial mindset include three phases: framing the praxis, amplification of one's own frame of reference, and reinterpretation of praxis. Once this sequence is achieved, the immediate learning outcomes can result in a change of mindset and behavior at the individual level. Further, this personal change may lead to transformational entrepreneurial behavior at the social/organizational level.

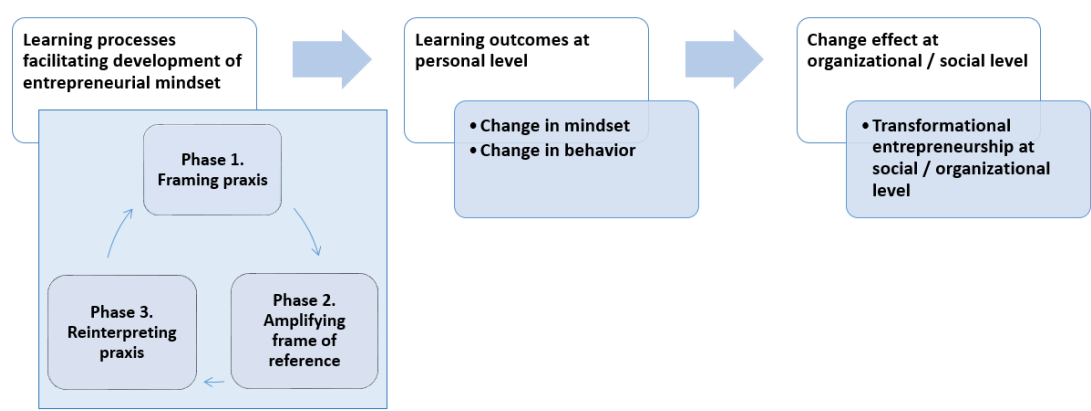

Figure 2. Conceptual model for the development of an entrepreneurial mindset for transformational entrepreneurship 


\section{CONCLUSION}

Drawing on the study of the TLC adult learning model, the paper set out to explore the learning processes facilitating the development of an entrepreneurial mindset for achieving transformational entrepreneurship. The findings reveal that such learning processes include three phases: framing the praxis, amplifying the frame of reference, and reinterpreting the praxis.

Framing the praxis was enforced by filling in the logs and critical event recognition. It is argued that reflective entrepreneurial learning starts with the ability to recognize a critical event (Cope \& Watts, 2000; Lindh \& Thorgren, 2016). The study suggests that projecting the work practice against entrepreneurial theory in the log system and extracting critical incidents triggered reflective processes among the TLC participants. This type of exercise assists entrepreneurs to recognize the events they should react to and learn from (ibid.).

Amplifying the frame of reference was triggered by collective discussions in the circles employing the logic of co-creation (e.g., Higgins, Smith, \& Mirza, 2013). In the TLC case, learning experiences were co-constructed with peers and facilitators through advising, reflexive questioning, challenging, and colliding viewpoints. Being exposed to different perspectives and ideas, the entrepreneurs started querying their practice and saw the need to explore alternative ways and options.

Finally, a reinterpretation of one's own praxis occurred while connecting the results of the circle meetings to the individual development projects. At this point, the participants were challenged to re-interpret, re-consider, self-assess, and, if necessary, correct the practice to produce a change. The combination of participatory dialogue and critical reflection (Mezirow, 2009) provided the metacognitive training necessary for transformative learning and the development of entrepreneurial thinking.

The contribution of this study to the literature on entrepreneurial learning is twofold. First, it explains how the key factors influencing entrepreneurial learning are connected to concrete learning processes facilitating the development of an entrepreneurial mindset for transformative entrepreneurship. Likewise, critical events recognition and logging assist to frame the individual's praxis by projecting their everyday work life through the lens of entrepreneurial theory. Co-creation of learning experiences helped to amplify the individual's frame of reference by embracing new ideas and perspectives in a more mindful way. Reinterpreting their own business practice by connecting group discussions to their own development projects triggered metacognitive thinking - a reflection on one's own learning. 
Furthermore, the three learning processes embrace the principles of experiential and transformative learning. The second contribution of the study is that it illustrates how these key factors may be utilized together in one learning model reinforcing the learning and transformative effect. According to Pittaway and Thorpe (2012) for effective entrepreneurial learning to take place, action must be followed by a high-level reflection. The study of the TLC exemplified how action and reflection may be organized in a loop through the three-phase learning process.

It is suggested that transformational entrepreneurship would be more acceptable and endorsed in the societies supporting participatory, humanoriented, team-oriented leadership styles (Ratten \& Jones, 2018). Even more so this concerns the learning setting that facilitates entrepreneurial mindsets for such entrepreneurship-setting that is participatory, democratic, facilitating individual and co-creative efforts. Speaking about learning outcomes and change effects, this study suggests that transformational entrepreneurship relates to transformations not only in value-creation activities but also in attitudes and behaviors.

The TLC model described in this study is not unproblematic, implying that the design of the model and its implementation posed certain challenges. Likewise, working with logs posed semantic and interpretational challenges: Is the log too general or too specific? Does it make sense for other participants? How to choose a critical incident? Technical challenges with the logs were connected to their complexity and dispersion in several text documents. Physical circle meetings presented another set of challenges, among which were language barriers (in some circles), securing equal participation of the circle members, and encouraging knowledge sharing (the facilitation function). Finally, while working with the individual development projects in between the circle meetings, participants could experience institutional barriers and lack of empowerment at the organizational level, as well as bounded individual cognition at a personal level. Therefore, educators preoccupied with the development of complex learning models, such as TLC, should be aware of the barriers and challenges similar to those described above, and try to address these concerns at the design stage.

While the model addressed in this study has a potential for further testing in other national, cultural, and educational settings, the three phases of the learning processes are what is to be taken further to embrace in educational and pedagogical practice for fostering transformational entrepreneurship.

The study of the TLC learning model provides some interesting implications for practice. First, the TLC model is essentially a "Nordic product" embracing the Nordic traditions for learning based on high involvement, participatory design and shared responsibility for learning. This differs from 
a top-down approach to learning where the educator or the course leader is the primary facilitator and carrier of knowledge. With the possibility of being integrated with different educational settings, the TLC model promotes broad participation where the learners act as active co-constructors of the learning processes. Second, the pilot implementation of the TLC model involved participants across different countries, cultures, educational backgrounds, professional experiences, organizations, and sectors. This diversity proved to contribute positively to the learning outcomes and transformational effect at the individual and organizational levels. It is therefore suggested here that there is a big potential to employ this model in the international settings charged with developing entrepreneurial and innovative thinking and elaborating solutions for complex social and organizational problems.

This piece of research supports Lindh \& Thorgren, 2016 who argue that entrepreneurial training should be designed in a way to promote participants' ability to recognize the critical events from which they should learn. This is opposed to the approach where the (prospective) entrepreneurs are presented with experiences from which they can learn. In the case of TLC, critical event recognition combined with logging served as an important tool for reflection, which provided participants with a wider range of meanings, paths, and consequences. Further, the development of an entrepreneurial mindset would benefit from the activities facilitating the dynamic loop of individual and collective participation, various modes of knowledge conversion, and connection to a concrete development project that would permit the interplay between experiential and theoretical knowledge. In this way, the three-phase learning processes of the TLC model present factors crucial for entrepreneurial learning - such as critical incidents, reflexive thinking, or co-creation of learning - in a systemic and interconnected way - as opposed to the literature focusing on one particular factor.

Major limitations of the study included relatively few circle meetings and short timeframes for data collection, which reduced the ability to trace the broad effect of transformational entrepreneurship at the social and organizational level.

Future research might extend the current study to one of addressing the development of entrepreneurial mindsets among less experienced entrepreneurs, entrepreneurs in developing countries, and transformational entrepreneurship for economic value creation, in order to assess how these various factors may affect learning processes and transformational outcomes. The findings of the study indicate that the process known as "unlearning" (e.g. McWilliam, 2008) is a constitutive element of developing an entrepreneurial mindset. The literature on entrepreneurial learning has not so far addressed 
this issue, and therefore future research may focus on the role of unlearning for the development of an entrepreneurial mindset.

This study suggests that through the learning processes that facilitate the framing of one's own experience and praxis, amplification of one's own frame of reference, and reinterpretation of one's own praxis, one may achieve a change in their mindset and behavior. Referring to Kotter, 2012, achieving transformation in mindsets and patterns of behavior is the first step to implementing large transformations at the organizational/business level.

\section{Acknowledgments}

The author thanks Nordic Network for Adult Learning (NVL) and the Nordic Council of Ministers for allowing the author to observe and conduct interviews during the TLC pilot project. A big thank you goes to the group of Nordic researchers from Inland Norway University of Applied Sciences and Uppsala University involved in the collection and analysis of data on the TLC pilot project. Finally, the author owes a debt of gratitude to two anonymous reviewers whose comments helped to essentially improve this piece of research.

\section{Attachment 1}

The Guiding principles of the Transformative Learning Circles.

\begin{tabular}{lll}
\hline GUIDING PRINCIPLES & KEY QUESTIONS & INDICATORS \\
\hline $\begin{array}{l}\text { No.1. Entrepreneurship } \\
\text { regarded as an organizational } \\
\text { or collective function. }\end{array}$ & $\begin{array}{l}\text { How can I collaborate } \\
\text { with others to bring } \\
\text { about a change in our } \\
\text { organization's way of } \\
\text { operating? }\end{array}$ & $\begin{array}{l}\text { New pattern of collaboration } \\
\text { initiated with one or more } \\
\text { colleague with the aim of } \\
\text { bringing about a change in } \\
\text { the organization's way of } \\
\text { operating. }\end{array}$ \\
\hline $\begin{array}{l}\text { No. 2. Entrepreneurial } \\
\text { actions derived from ethical } \\
\text { principles of global social } \\
\text { responsibility, solidarity, and } \\
\text { sustainability. }\end{array}$ & $\begin{array}{l}\text { How will the actions } \\
\text { I plan to engage in, in the } \\
\text { first instance, enable our } \\
\text { organization to better } \\
\text { contribute towards a more } \\
\text { humane and sustainable } \\
\text { society? }\end{array}$ & $\begin{array}{l}\text { One or more aspects of } \\
\text { a society conducive to } \\
\text { human flourishing in a global } \\
\text { perspective identified. } \\
\text { One or more connections } \\
\text { between the organization's } \\
\text { way of operating and the } \\
\text { above aspects identified. }\end{array}$ \\
\hline $\begin{array}{l}\text { No. 3. Entrepreneurship } \\
\text { aimed, in the first instance, } \\
\text { at helping a collective (an } \\
\text { organization, a community, } \\
\text { the global society) realize } \\
\text { their best potentialities. }\end{array}$ & $\begin{array}{l}\text { What as yet not (sufficiently) } \\
\text { realized potentials are there } \\
\text { in our organization that we } \\
\text { could engage in realizing? }\end{array}$ & $\begin{array}{l}\text { One or more potentials or } \\
\text { unrealized possibilities in the } \\
\text { organization's operations, } \\
\text { in keeping with the above, } \\
\text { identified. }\end{array}$ \\
& & $\begin{array}{l}\text { One of measures undertaken } \\
\text { to realize these potentials. }\end{array}$ \\
\hline
\end{tabular}


100 / Developing entrepreneurial mindset for transformational entrepreneurship:

The case of Nordic transformative learning circles

\begin{tabular}{|c|c|c|}
\hline GUIDING PRINCIPLES & KEY QUESTIONS & INDICATORS \\
\hline $\begin{array}{l}\text { No. 4. Entrepreneurial } \\
\text { innovation seeking primarily } \\
\text { to transform the culture } \\
\text { (the prevalent values, the } \\
\text { quality of relationships, the } \\
\text { meaningfulness of processes) } \\
\text { of an organization. }\end{array}$ & $\begin{array}{l}\text { How will what I plan to } \\
\text { engage in bring about } \\
\text { fundamental changes in } \\
\text { the way our organization } \\
\text { operates? }\end{array}$ & $\begin{array}{l}\text { Specific needs for changes } \\
\text { in the values and ethical } \\
\text { principles underlying the } \\
\text { organization's way of } \\
\text { operating towards a greater } \\
\text { degree of human flourishing } \\
\text { and sustainability identified. }\end{array}$ \\
\hline $\begin{array}{l}\text { No. } 5 \text {. Personal growth and } \\
\text { development regarded } \\
\text { valuable as a necessary } \\
\text { requirement for being able to } \\
\text { better serve the wellbeing of } \\
\text { a collective (an organization, } \\
\text { a community, the global } \\
\text { society) }\end{array}$ & $\begin{array}{l}\text { How do I need to change } \\
\text { myself in order to be able to } \\
\text { better serve my organization } \\
\text { and the global society? }\end{array}$ & $\begin{array}{l}\text { Needs for personal } \\
\text { development identified } \\
\text { in the light of increased } \\
\text { capability to serve the } \\
\text { organization and society at } \\
\text { large in their development } \\
\text { towards a higher level } \\
\text { of humaneness and } \\
\text { sustainability. }\end{array}$ \\
\hline
\end{tabular}

\section{Attachment 2}

Each participant keeps a logbook between meetings. You should fill out General individual log and Critical Incident log. Tag it with " $\mathrm{P}$ " or " $\mathrm{O}$ " ( $\mathrm{P}=$ personal, $\mathrm{O}=$ organizational) in order to reflect upon what are individual elements and what are organizational.

\section{General Individual Log}

Entry date:

\begin{tabular}{llll}
\hline EFFORT & $\begin{array}{l}\text { GUIDING } \\
\text { PRINCIPLE }\end{array}$ & $\begin{array}{l}\text { TRANSFORMATION } \\
\text { INDICATOR }\end{array}$ & LEARNING \\
\hline $\begin{array}{l}\text { Here you describe } \\
\text { what you have } \\
\text { done to bring } \\
\text { about a change in } \\
\text { yourself or in your } \\
\text { organization. }\end{array}$ & $\begin{array}{l}\text { Here you explain } \\
\text { phinch guiding }\end{array}$ & $\begin{array}{l}\text { Here you describe } \\
\text { the transformation }\end{array}$ & $\begin{array}{l}\text { Here you describe } \\
\text { that you and your }\end{array}$ \\
& & $\begin{array}{l}\text { you think has taken } \\
\text { place and the }\end{array}$ & $\begin{array}{l}\text { organization have } \\
\text { learned, what has } \\
\text { indicator(s) thereof. }\end{array}$ \\
& & & $\begin{array}{l}\text { facilitated that } \\
\text { learning, and how } \\
\text { the learning has } \\
\text { brought you closer } \\
\text { to the realization } \\
\text { of your vision. }\end{array}$
\end{tabular}


Critical Incidence Log

Entry date:

\begin{tabular}{|c|c|c|c|}
\hline $\begin{array}{l}\text { CRITICAL } \\
\text { INCIDENCE }\end{array}$ & $\begin{array}{l}\text { GUIDING } \\
\text { PRINCIPLE }\end{array}$ & LEARNING & $\begin{array}{l}\text { EFFECT (extra } \\
\text { information) }\end{array}$ \\
\hline $\begin{array}{l}\text { Here you describe } \\
\text { a critical incidence } \\
\text { pertaining to } \\
\text { personal or } \\
\text { organizational } \\
\text { transformation. } \\
\text { A critical incidence } \\
\text { is an incidence } \\
\text { that has had } \\
\text { a decisive impact } \\
\text { on a transformative } \\
\text { process or itself } \\
\text { has embodied } \\
\text { a transformative } \\
\text { event. }\end{array}$ & $\begin{array}{l}\text { Here you explain } \\
\text { what guiding } \\
\text { principle the } \\
\text { critical incidence } \\
\text { has been an } \\
\text { enactment of. }\end{array}$ & $\begin{array}{l}\text { Here you describe } \\
\text { the transformation } \\
\text { that took place } \\
\text { as a result of the } \\
\text { incidence and } \\
\text { what you and your } \\
\text { organization have } \\
\text { learned from the } \\
\text { incidence }\end{array}$ & $\begin{array}{l}\text { Here you describe } \\
\text { what you consider } \\
\text { as the effect for } \\
\text { you and your } \\
\text { organization }\end{array}$ \\
\hline
\end{tabular}

Individual learning log that you want to share with your circle at your next meeting

Entry date:

\begin{tabular}{|c|c|}
\hline A PROCESS/AN INCIDENCE & LEARNING GAINED \\
\hline $\begin{array}{l}\text { Choose one (critical) incidence or } \\
\text { process from your personal log book } \\
\text { that you feel has been particularly } \\
\text { successful and that you want to share } \\
\text { with your Circle at the next meeting. } \\
\text { Write a description of what was done } \\
\text { and what happened as a result. }\end{array}$ & $\begin{array}{l}\text { Give your own analysis of what you/your } \\
\text { organization have/has learned about } \\
\text { enacting and applying guiding principles } \\
\text { and the common goal state vision }\end{array}$ \\
\hline
\end{tabular}

\section{Meeting Learning Evaluation Log}

1) Each participant takes up one aspect of the learning process carried out during the meeting that (s)he thinks was particularly successful and, if (s)he so feels, one aspect that (s)he thinks requires especially further development. The aspects are to be presented in the form of pictures that are then commented upon.

2) With the help of the facilitator, these views are summarized (closely related points categorized), leading to $1-3$ points (in pictorial form) to be discussed. 
3) The points are discussed by the Circle with the purpose of arriving at a unified understanding and decision(s), presented in pictorial form, as to:

a) what currently are some of the Circle's learning strengths and how the Circle can build on these in the future.

b) what currently are some of the Circle's learning needs and how these can be addressed in the future.

In stating and discussing learning needs, it is important that each participant voice her/his experiences and interpretations without accusing anyone. The purpose is to find a collective way forward, if possible, based on the identified strengths.

4) The evaluation part is closed with the facilitator recapping the identified learning strengths (showing the pictures depicting these).

\section{References}

Burkhalter, S., Gastil, J., \& Kelshaw, T. (2002). A conceptual definition and theoretical model of public deliberation in small face-toface groups. Communication Theory, 12(4), 398-422. https://doi. org/10.1111/j.1468-2885.2002.tb00276.x

Cho, Y. S., \& Jung, J. Y. (2014). The relationship between metacognition, entrepreneurial orientation, and firm performance: An empirical investigation. Academy of Entrepreneurship Journal, 20(2), 71-86.

Cope, J. (2003). Entrepreneurial learning and critical reflection: Discontinuous events as triggers for 'higher-level'learning. Management Learning, 34(4), 429-450. https://doi.org/10.1177/1350507603039067

Cope, J., \& Watts, G. (2000). Learning by doing-an exploration of experience, critical incidents and reflection in entrepreneurial learning. International Journal of Entrepreneurial Behavior \& Research, 6(3), 104-124. https:// doi.org/10.1108/13552550010346208

Dewey, J. (1986). Experience and education. The Educational Forum, 50(3), 241-252. https://doi.org/10.1080/00131728609335764

Fayolle, A., Pittaway, L., Politis, D., \& Toutain, O. (2014). Entrepreneurial learning: Diversity of education practices and complexity of learning processes. Entrepreneurship \& Regional Development, 26(3-4), 1-3. https://doi.org/10.1080/08985626.2014.911426

Ghauri, P., \& Grønhaug, K. (2005). Research Methods in Business Studies. A Practical Guide (Third ed.). New York: Prentice Hall.

Haynie, J. M., Shepherd, D., Mosakowski, E., \& Earley, P. C. (2010). A situated metacognitive model of the entrepreneurial mindset. Journal of 
Business Venturing, 25(2), 217-229. https://doi.org/10.1016/j. jbusvent.2008.10.001

Higgins, D., \& Elliott, C. (2011). Learning to make sense: What works in entrepreneurial education? Journal of European Industrial Training, 35(4), 345-367. https://doi.org/10.1108/03090591111128324

Higgins, D., Smith, K., \& Mirza, M. (2013). Entrepreneurial education: Reflexive approaches to entrepreneurial learning in practice. The Journal of Entrepreneurship, 22(2), 135-160. https://doi. org/10.1177/0971355713490619

Kakouris, A. (2015). Entrepreneurship pedagogies in lifelong learning: Emergence of criticality? Learning, Culture and Social Interaction, 6, 8797. https://doi.org/10.1016/j.lcsi.2015.04.004

Kolb, D. A. (2015). Experiential Learning: Experience as the Source of Learning and Development (Second ed.). Upper Saddle River, New Jersey: Pearson Education.

Kotter, J. P. (2012). Leading Change. Boston, Massachusetts: Harvard Business Review Press.

Krueger, N. F. (2007). What lies beneath? The experiential essence of entrepreneurial thinking. Entrepreneurship Theory and Practice, 31(1), 123-138. https://doi.org/10.1111/j.1540-6520.2007.00166.x

Lamberton, D. M. (2005). Information sharing. In D. Rooney, G. Hearn, \& A. Ninan (Eds.), Handbook on the Knowledge Economy (pp. 155-164). Cheltenham, UK; Northampton, MA: Edward Elgar Publishing.

Leon, R. D. (2017). Developing entrepreneurial skills. An educational and intercultural perspective. Journal of Entrepreneurship, Management and Innovation, 13(4), 97-121. https://doi.org/10.7341/20171346

Liang, C.-T., Lee, J.-L., \& Liang, C. (2015). Interaction of psychological factors in shaping entrepreneurial intention among computer and electrical engineering students. Journal of Entrepreneurship, Management and Innovation, 11(2), 5-29. https://doi.org/10.7341/20151121

Lincoln, Y. S., \& Guba, E. G. (1985). Establishing trustworthiness. In Naturalistic Inquiry (pp. 289-327). Newbury Park, CA: SAGE Publications.

Lindh, I., \& Thorgren, S. (2016). Critical event recognition: An extended view of reflective learning. Management Learning, 47(5), 525-542. https:// doi.org/10.1177/1350507615618600

Maas, G., Jones, P., \& Lockyer, J. (2016). A position paper for International Centre for Transformatinal Entrepreneurship at Coventry University. Retrieved from https://pureportal.coventry.ac.uk/en/publications/ position-paper-international-centre-for-transformational-entrepre

McGrath, R. G., \& MacMillan, I. C. (2000). The Entrepreneurial Mindset: Strategies for Continuously Creating Opportunity in an Age of Uncertainty. Boston, Massachusetts: Harvard Business School Press.

McWilliam, E. (2008). Unlearning how to teach. Innovations in Education and Teaching International, 45(3), 263-269. https://doi. org/10.1080/14703290802176147 
Mezirow, J. (1978). Perspective transformation. Adult Education, 28(2), 100110. https://doi.org/10.1177/074171367802800202

Mezirow, J. (1991). Transformative Dimensions of Adult Learning. San Francisco: Jossey-Bass.

Mezirow, J. (2003). Transformative learning as discourse. Journal of Transformative Education, 1(1), 58-63. https://doi. org/10.1177/1541344603252172

Mezirow, J. (2009). An overview on transformative learning. In K. Illeris (Ed.), Contemporary Theories of Learning (pp. 109-125). New York: Routledge.

Miller, R. A., \& Collier, E. W. (2010). Redefining entrepreneurship: A virtues and values perspective. Journal of Leadership, Accountability and Ethics, $8(2), 80-89$.

Namdar, K. (2016). Evaluation design for the NVL project: Fostering transformative entrepreneurship through transformative learning circles. A position paper for the NVL Network, the Nordic Council of Ministers.

Ndlela, M., Hole, Å. S., Slettli, V. K., Haave, H., Mei, X. Y., Lundesgaard, D., Namdar, K. (2019). Facilitation of learning in Transformative Learning Circles: Enabling entrepreneurial mindsets through co-creation of knowledge. In D. Higgins, P. Jones, \& P. McGowan (Eds.), Creating Entrepreneurial Space: Talking through Multi Voices, Reflections on Emerging Debates (Vol. 9, pp. 73-93): London: Emerald Publishing Limited.

Nonaka, I., \& Von Krogh, G. (2009). Tacit knowledge and knowledge conversion: Controversy and advancement in organizational knowledge creation theory. Organization Science, 20(3), 635-652. https://doi. org/10.1287/orsc.1080.0412

Oyugi, J. L. (2015). The mediating effect of self-efficacy on the relationship between entrepreneurship education and entrepreneurial intentions of university students. Journal of Entrepreneurship, Management and Innovation, 11(2), 31-56. https://doi.org/10.7341/20151122

Pittaway, L., \& Thorpe, R. (2012). A framework for entrepreneurial learning: A tribute to Jason Cope. Entrepreneurship \& Regional Development, 24(9-10), 837-859. https://doi.org/10.1080/08985626.2012.694268

Ramsey, R. E., \& Miller, D. J. (Eds.). (2003). Experiences between Philosophy and Communication: Engaging the Philosophical Contributions of Calvin O. Schrag. New York: State University of New York Press.

Ratten, V., \& Jones, P. (Eds.). (2018). Transformational Entrepreneurship. London: Routledge.

Ravensbergen, F., \& Vanderplaat, M. (2010). Learning circles: One form of knowledge production in social action research. McGill Journal of Education, 45(3), 339-350. https://doi.org/10.7202/1003566ar

Reason, P., \& Rowan, J. (Eds.). (1981). Human Inquiry: A Sourcebook of New Paradigm Research. Chichester [England]; New York: John Wiley \& Sons. 
Ritchie, J., Lewis, J., Nicholls, C. M., \& Ormston, R. (2013). Qualitative Research Practice: A Guide for Social Science Students and Researchers (Second ed.). Thousand Oaks, CA: SAGE Publications.

Staffas, K. (2017). Evaluation of Transformative Learning Circles: A learning model from an NVL pilot project. Retrieved from http://www.diva-portal. org/smash/get/diva2:1184507/FULLTEXT01.pdf

Stein, D. (2009). The use of deliberative discussion to enhance the critical thinking abilities of nursing students. Journal of Public Deliberation, 5(1), 1-18.

Taylor, D. W., \& Thorpe, R. (2004). Entrepreneurial learning: A process of coparticipation. Journal of Small Business and Enterprise Development, 11(2), 203-211. https://doi.org/10.1108/14626000410537146

Tikkamäki, K., Heikkilä, P., \& Ainasoja, M. (2016). Positive stress and reflective practice among entrepreneurs. Journal of Entrepreneurship, Management and Innovation, 12(1), 35-56. https://doi.org/10.7341/20161212

Täks, M., Tynjälä, P., \& Kukemelk, H. (2016). Engineering students' conceptions of entrepreneurial learning as part of their education. European Journal of Engineering Education, 41(1), 53-69. https://doi.org/10.1080/030437 97.2015.1012708

Woods, P. (2012). Critical Events in Teaching and Learning. New York: Routledge.

\begin{abstract}
Abstrakt
Rozwój myślenia przedsiębiorczego był ostatnio przedmiotem obrad polityków UE $i$ jest przedmiotem troski nauczycieli. Tradycyjne podejście do edukacji przedsiębiorczej nie uwzględnia dwuznaczności procesu przedsiębiorczości. Niniejszy artykuł ma na celu zbadanie procesów uczenia się, które przyczyniaja się do rozwoju ducha przedsiębiorczości w zakresie przedsiębiorczości transformacyjnej. Przedsiębiorczość transformacyjna odnosi się do zdolności i zamierzonego działania na rzecz zmiany $w$ życiu przedsiębiorcy i organizacji, która przyczynia się do zmian społecznych i charakteryzuje się pojawieniem się nowego jakościowego wymiaru możliwości. Aby promować przedsiębiorczość transformacyjnq, Nordic Network for Adult Learning opracował szczególny model uczenia się dorosłych, znany jako Transformative Learning Circles (TLC), przy wsparciu Nordyckiej Rady Ministrów. Artykuł opiera się na badaniu pilotażowego wdrożenia modelu TLC w kontekście krajów skandynawskich. Odkrycia ujawniajq, że procesy uczenia się promujqce ducha przedsiębiorczości dla transformacyjnej przedsiębiorczości zachodzq w trzech konkretnych fazach: 1) kształtowanie praktyki; 2) wzmocnienie ramy odniesienia; oraz 3) reinterpretacja praktyki. Badanie poszerza obecnq wiedzę na temat uczenia się przedsiębiorczości na dwa sposoby. Po pierwsze, łq̨czy kluczowe czynniki wpływajqce na uczenie się przedsiębiorczości z konkretnymi procesami uczenia się, ułatwiajq̨cymi rozwój ducha przedsiębiorczości dla transformacyjnej przedsiębiorczości. Po drugie, ilustruje, w jaki sposób te kluczowe czynniki mogq być wykorzystane razem w jednym modelu uczenia się wzmacniajqcym efekt uczenia się i transformujq̨cy.
\end{abstract}

